ix, no. I (1966), pp. 24-32) which examined opportunities for increasing co-operation between U.S. scholars concerned with Africa and individuals and academic institutions based in Africa. Scholars from the United States constitute the largest single national group engaged in African research. To faciliate communication the R.L.C. is collecting information and identifying sources of information for American scholars and students proposing research in African studies. The Committee has established an office in New York at the same address as the Association's offices and under the direction of William O. Brown, with Shirley Fischer as Administrative Secretary. The objectives are to develop and strengthen relations among scholars concerned with Africa, and to maintain liaison with research institutions in Africa through visits to Africa by members of the Committee. The office will serve the interests of scholarship by providing a series of related services designed to supply information about the constantly changing research scene in Africa, namely:

1. To supply information about American scholars now in Africa, or who have recently returned, and about research in progress from an annotated list of proposed, on-going, and recently completed research.

2. To provide a centre through which colleagues in Africa may address their research needs, recommendations, questions, or grievances relating to the role of American research in Africa,

3. To maintain a series of multilith information sheets, by country and for Africa in general, concerning such matters as living conditions, government regulations governing research, currency, health, climate, taxes, and visas.

4. To assist both younger scholars and established researchers in making appropriate contacts in Africa.

5. To maintain liaison with other African studies associations both in Africa and in other parts of the world.

6. To publish information of interest to Africanist scholars from time to time in the African Studies Bulletin.

Correspondence should be addressed to : Shirley K. Fischer, Research Liaison Committee,

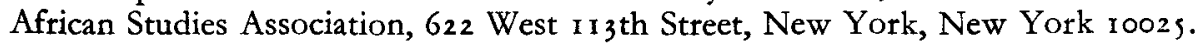

\title{
UNESCO Project for a General History of Africa
}

RESOLUTION 3.442 of the General Conference of UNESCO, at its thirteenth session in 1965, authorized the Director-General ' to take the necessary measures for the preparation and publication, over a ten-year period from 1965 to 1975 , of a General History of Africa'. The Director-General entrusted Dr. K. O. Dike, President of the International Congress of Africanists, with the direction of the ten-year project. A committee of scholars was convened at Abidjan, Ivory Coast, from 3 I August to S September 1966, under the chairmanship of Dr. Dike and with M. Bammate representing the Director-General. Professor J. Ki-Zerbo was elected vice-chairman of the committee, and Professor M. Lacheraf as rapporteur. A wide representation was intended although numbers had been restricted for the sake of efficiency. Unfortunately several of those invited were not able to attend.

The terms of reference were to reach practical recommendations on the priority tasks, and to suggest the means to accomplish them. The following recommendations were made: (I) to co-ordinate the various efforts under way to publish guides to African materials in a number of archives throughout the world; (2) to undertake the preparation of a manual for the guidance of those who might record oral traditions, and for the establishment in 
Africa of archives for the preservation of these recordings-this was given the highest priority by the committee; (3) to accept a preliminary outline of the periodization and regionalization of African history; (4) to invite the co-operation of other disciplines; (5) to promote the publication of teaching aids as well as materials of specialist interest; $(6)$ to further co-operation between UNESCO and institutes of African studies; (7) to create a permanent consultative committee; (8) to begin a summary of our knowledge of the nineteenth century, which was recognized as the most researched period at the moment, and to encourage research in a number of more neglected areas.

The recommendations were submitted to the fourteenth session of the General Conference of UNESCO, which met in October 1966.

\section{Un Colloque international d'Archéologie africaine à Fort-Lamy}

De nombreux archéologues venus d'Afrique du Nord, d'Afrique occidentale, d'Afrique centrale, d'Afrique orientale, de France, d'Allemagne, d'Italie et des États-Unis, principalement, se sont réunis à l'Institut national tchadien pour les Sciences humaines de FortLamy du i i au i6 décembre 1966.

Les participants à ce colloque, organisé par l'UNESCO et le Gouvernement de la République du Tchad avec le patronage scientifique du Centre national de la Recherche scientifique (Paris), étaient les suivants : Mlle Aumassip (Centre de Recherches anthropologiques, préhistoriques et ethnographiques, Alger), M. Awad Saadawia (Direction des services libyens d'archéologie), M. G. Bailloud (CNRS), M. le Doyen L. Balout (Université de Paris et Muséum national d'Histoire naturelle), M. G. de Beauchêne (IFAN, Niger), M. B. Blankoff (Société de préhistoire du Gabon), M. le Professeur et Mme Camps (Université et Centre de Recherches anthropologiques, préhistoriques et ethnographiques d'Alger), M. Brahim Benoît (INTSH), M. J. Chapelle (INTSH et Musée national tchadien), M. G. E. Connah (Université d'Ibadan), M. le Professeur C. S. Coon (Université de Philadelphie), Dr. Y. Coppens (CNRS), M. Courtin (CNRS), M. Ekpo Eyo (Directeur Adjoint des Antiquités, Nigeria), M. Gamacchio (Fondation Lerici, Milan), M. J. Gauthier (CNRS), Dr. J. H. Hugot (IFAN, Dakar), M. Hurel (UNESCO), M. Jauffret (Directeur des Services géologiques, Fort-Lamy), M. le Professeur J. Leclant (Université de Paris), M. le Professeur et Mme Lebeuf (CRNS), M. H. Lhote (CNRS et Musée de l'Homme), M. le Professeur Monod, Membre de l'Académie des sciences (Muséum national d'Histoire naturelle), Dr. R. B. Nunoo (Directeur du Musée national ghanéen), Dr. Posnansky (Directeur des études africaines, Kampala), M. J. P. Roset (ORSTOM), Mme Roubet (Centre de Recherches anthropologiques, préhistoriques et ethnographiques, Alger), M. Rollando (France), Dr. Schläger (Institut allemand d'Archéologie, Rome), M. Schneider (B.R.G.M., FortLamy), M. le Professeur Thurstan Shaw (Université d'Ibadan), M. le Dr. Ziegert (Institut allemand de Bardaï).

Ce colloque, qui constitue une entreprise de groupement régional du même ordre que le récent Séminaire d'archéologie de Freetown (28 et 29 juin 1966) représenté à Fort-Lamy par le Professeur Thurstan Shaw, a fait état des recherches poursuivies dans une grande partie de l'Afrique. Il a rédigé des vœux à soumettre aux gouvernements intéressés et des recommandations destinées aux organismes de recherches spécialisés en insistant tout particulièrement sur l'importance de l'enseignement de la préhistoire africaine et de son intégration à la formation générale des historiens de l'Afrique, sur la réunion régulière de colloques régionaux et sur l'urgence de la formation intensive d'archéologues nationaux africains. Il a travaillé en liaison avec les Congrès internationaux de préhistoire et d'étude du quaternaire qui étaient représentés au Colloque de Fort-Lamy par M. le Doyen L. Balout. 